\title{
Damming the rivers of the Amazon Basin
}

Edgardo M. Latrubesse ${ }^{1,2}$, Eugenio Y. Arima ${ }^{1}$, Thomas Dunne ${ }^{3}$, Edward Park ${ }^{1}$, Victor R. Baker ${ }^{4}$, Fernando M. d'Horta ${ }^{5}$, Charles Wight $^{1}$, Florian Wittmann ${ }^{6}$, Jansen Zuanon ${ }^{5}$, Paul A. Baker ${ }^{7}$, Camila C. Ribas ${ }^{5}$, Richard B. Norgaard ${ }^{8}$, Naziano Filizola $^{9}$, Atif Ansar ${ }^{10}$, Bent Flyvbjerg ${ }^{10}$, and Jose C. Stevaux ${ }^{11}$

${ }^{1}$ University of Texas at Austin, Department of Geography and the Environment, USA

${ }^{2}$ Earth Observatory of Singapore and Asian School of the Environment, Nanyang Technological University, Singapore

${ }^{3}$ University of California at Santa Barbara, Bren School of Environmental Science and Management, USA

${ }^{4}$ University of Arizona, Department of Hydrology and Atmospheric Sciences, USA

${ }^{5}$ National Institute of Amazonian Research (INPA), Brazil

${ }^{6}$ Institute of Floodplain Ecology, Karlsruhe Institute of Technology, Germany

${ }^{7}$ Duke University, Nicholas School of the Environment, USA; Yachay Tech, Geological Sciences, Ecuador

${ }^{8}$ University of California at Berkeley, Energy and Resources Group, USA

${ }^{9}$ Federal University of Amazonas, Department of Geography, Brazil

${ }^{10}$ University of Oxford, Saïd Business School, UK

${ }^{11}$ State University of Sao Paulo (UNESP-Rio Claro), Department of Applied Geology, Brazil

\section{Summary}

More than 100 hydropower dams have already been built in the Amazon basin and numerous proposals for further dam constructions are under consideration. The accumulated negative environmental effects of built and proposed dams, if constructed, will trigger massive hydrophysical and biotic disturbances that will impact the Amazon basin's floodplains, estuary, and sediment plume. By introducing a Dam Environmental Vulnerability Index (DEVI) we quantify the current and potential impacts of dams in the basin. The scale of foreseeable environmental degradation indicates the need for collective action among nations and states to avoid cumulative, far-field impacts. We suggest institutional innovations to assess and avoid the likely impoverishment of Amazon rivers. 
Dams in Amazonia have induced confrontations among developers, governmental officials, indigenous populations, and environmentalists. Amazonian hydroelectric dams are commonly justified on the basis of providing renewable energy and avoiding carbon emissions, while supplying energy needed for economic development. Recent scientific reviews have considered environmental impacts of damming Amazonian rivers ${ }^{1-3}$, but regrettably, the effects of dams have mainly been assessed through studies undertaken only in the vicinity of each dam ${ }^{4}$. Such a local-scale approach generally ignores the far larger, basin-scale, geomorphological, ecological, and political dimensions that will determine the future productive and environmental condition of the river system as a whole. For networks of large dams on mega rivers ${ }^{5}$, far less consideration has been given to the need for assessing environmental impacts at regional to continental scales.

There is ample evidence that systems of large dams on trunk rivers and tributaries, constructed without anticipation of cumulative consequences, lead to large-scale degradation of floodplain and coastal environments ${ }^{6-8}$. In the Amazon, basinwide assessments are complex and involve multiple countries and state institutions. Yet, because the social and environmental impacts of large dams are severe, disruptive, and characteristically irreversible ${ }^{9,10}$, there is a pressing need for assessment of the nature and exceptional international scale of their environmental impacts and for systematic consideration of their selection, design, and operation in order to minimize these deleterious aspects. System-wide evaluation could also be used as a basis for examining trade-offs between energy production and other economic and socio-environmental values, and for anticipating and ameliorating unavoidable changes to economies, navigation, biodiversity, and ecosystem services.

Herein, we provide an analysis of the current and expected environmental consequences that will occur at multiple scales if the proposed widespread construction of Amazonian dams goes forward. We move beyond qualitative statements and critiques by introducing new metrics - specifically a Dam Environmental Vulnerability Index or DEVI - to quantify the impacts of 140 constructed and under construction dams, and the potential impact of 428 built and planned dams $\geq 1 \mathrm{MW}$ in the Amazon basin. We find the dams - even if only a fraction of those planned are built - will have significant environmental consequences with no imaginable restoration technology. These include massive hydrophysical and biotic disturbances of the Amazon floodplain, estuary, and its marine sediment plume, the northeast coast of South America, and regional climate. However, the extent and intensity of impacts on specific biological groups are uncertain and need to be explored during future work.

We assessed the current and potential vulnerabilities of different regions of the Amazon basin and highlight the need for a more efficient and integrative legal framework involving all nine countries of the basin in an anticipatory assessment of how the negative socio-environmental and biotic impacts of hydropower development can be minimized to achieve environmental benefits for the relevant riverine communities and nations. 

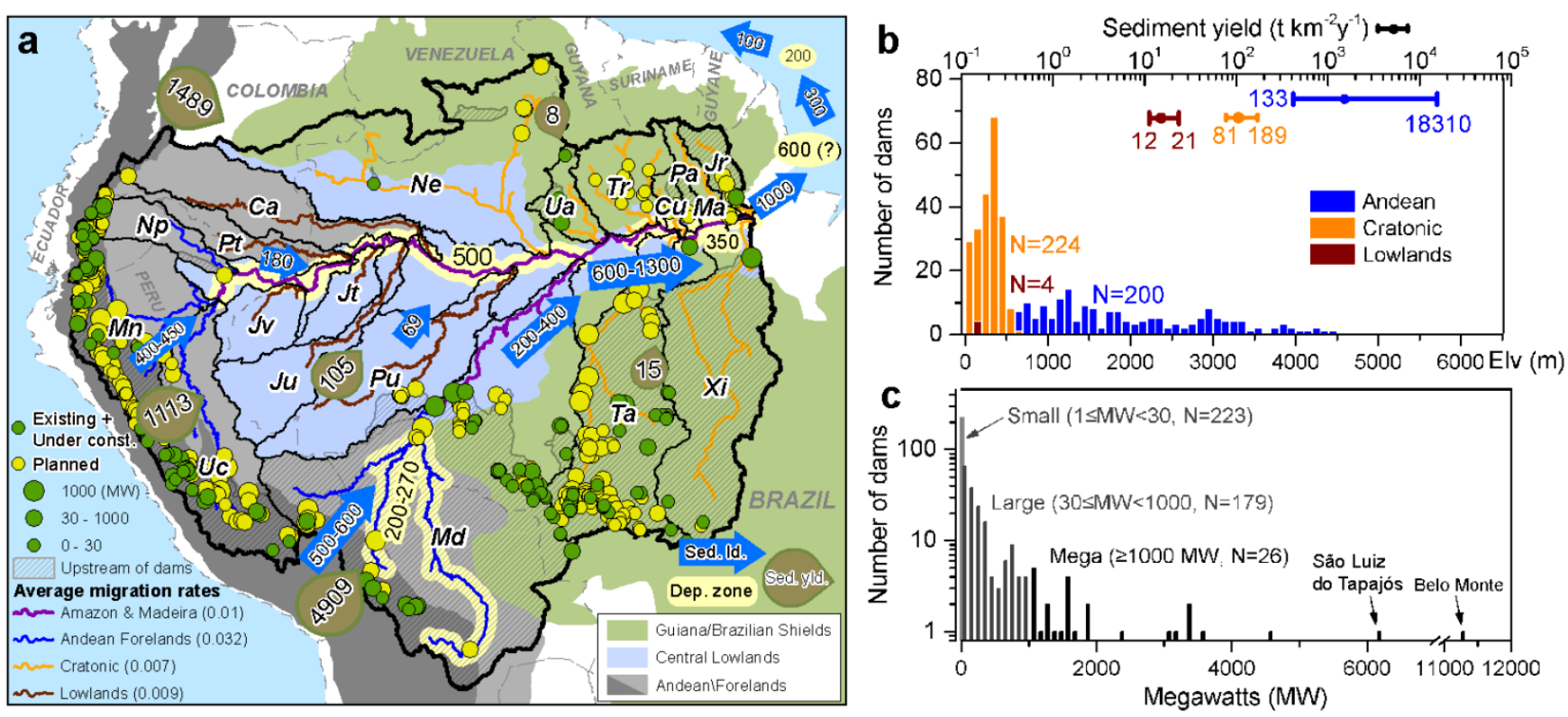

Fig. 1 The Amazon's 19 sub-basins: geologic-physiographic domains, sediments fluxes, channel migration rates and dams. (a) Andean-foreland rivers: Marañon $(\mathrm{Mn})$, Ucayali $(U c)$, Napo $(\mathrm{Np})$, Putumayo (Pt), Caqueta $(\mathrm{Ca})$; $\underline{\mathrm{Cratonic}}$ rivers: Jari $(\mathrm{Jr})$, Paru $(\mathrm{Pa})$, Curuapenema $(\mathrm{Cu})$, Maricuru $(\mathrm{Ma})$, Tapajós $(\mathrm{Ta})$, Xingu $(\mathrm{Xi})$, Trombetas $(\mathrm{Tr})$, Negro $(\mathrm{Ne})$, Uatumã $(U a)$; Mixed-terrain rivers: Madeira $(M d)$; Lowland rivers: Juruá $(J u)$, Purús $(P u)$, Jutaí $(J t)$, Javari $(J v)$. Averaged sediment yield $\left(\mathrm{t} \mathrm{km}^{2} \mathrm{y}^{-1}\right)$ for major sediment source terrains (brown balloons) ${ }^{12,20}$; fluxes of sediment $\left(\mathrm{Mt} \mathrm{yr}^{-1}\right)$

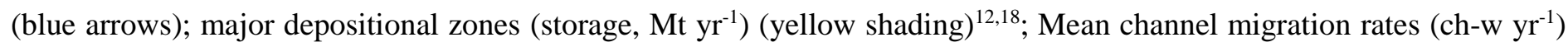
by physiographic provinces ${ }^{23}$ (red, green and blue lines) are shown. Migration rates of 0.01 were estimated for the Solimões-Amazon and Madeira rivers (purple line). (b) Numbers of dams in each elevation range (bars) and geological region (Andean, Cratonic, and Lowlands). Ranges and means of sediment yields $\left(\mathrm{t} \mathrm{km}^{-2} \mathrm{yr}^{-1}\right)$ measured in each region (color coded) are shown along the upper x-axis. (c) Histogram of the number of dams scaled by their hydroelectric capacity (MW).

\section{Amazonian rivers and dams}

The Amazon River system and its watershed of 6,100,000 $\mathrm{km}^{2}$ comprise Earth's most complex and largest network of river channels, and a diversity of wetlands that is exceptional in both biodiversity and primary and secondary productivity ${ }^{11}$. The river basin discharges $\sim 16$ to $18 \%$ of the planet's fresh water flow to its large estuary and the nearshore Atlantic ${ }^{12,13}$. Four of the world's ten largest rivers are in the Amazon basin (the Amazon, Negro, Madeira and Japurá), and twenty of the 34 largest tropical rivers are Amazonian tributaries ${ }^{14}$. The Amazon is also the largest and most complex river system that transfers sediments and solutes across continental distances, constructing and sustaining Earth's largest continuous belt of floodplain and a mosaic of wetlands encompassing more than $1,000,000 \mathrm{~km}^{2}$.

The sediment regimes and geochemistry of Amazon tributaries differ according to the dominant geotectonic regions that they drain ${ }^{15}$. Andean or Andean-foreland are rich in suspended sediment and solute loads, and the water $\mathrm{pH}$ is near-neutral Cratonic rivers are characterized by low suspended load and $\mathrm{pH}$, and often highly enriched in dissolved and particulate organic carbon. Lowland rivers drain sedimentary rocks and transport an abundant suspended sediment load entirely within the tropical rainforest. A fourth mixed-terrain category including Andean, foreland and cratonic areas applies only to the Madeira basin because of the complexity of its geotectonic domains.

The fluvial channels and floodplain morphologies, the amount and characteristics of the sediments transported by the rivers, the annual flood-pulse, and the action of morphodynamic erosional-depositional processes in space and time, provide disturbance regimes that result in high habitat diversity of the alluvial landscape, high biotic diversity, and high levels of endemism for both aquatic and non-aquatic organisms ${ }^{16,17}$. 
We identified 76 existing dams or dams under construction on the cratonic rivers of the Amazon basin, 62 in the Andes, and two dams in the foreland-cratonic transition, in the Madeira River. Planned installations include 136, 146, and 6 dams in the Andean, cratonic, and lowland environments respectively. The proposed dams include small, large and mega projects that account for $48 \%, 45 \%$, and $7 \%$ of the total number respectively (Fig. 1 and Supplementary KMZ files). Three of the ten largest mega dams in terms of power generation are built or near completion: Belo Monte (11,233 MW) on the Xingu River; Santo Antônio (3,150 MW) and Jirau (3,750 MW) on the Madeira River. The remaining seven largest are still in planning stages, underlining the need for immediate attention to the impacts of these mega construction projects. The only planned Andean storage mega dam in the top ten is on the Marañon (4,500 MW) River in Peru, but many others have been proposed for the sediment-rich Andean source regions (Fig.1).

\section{Dam Environmental Vulnerability Index}

Here we present a Dam Environmental Vulnerability Index (DEVI) and undertake a large-scale assessment of the environmental impact of existing, and planned Amazonian dams. This allows us to provide vulnerability maps for the 19 major Amazon sub-basins by considering two scenarios: existing and under-construction dams in 2017 (Supplementary Fig.2), and all dams, existing, under-construction, and planned (Fig.2).

The DEVI is a measure of the vulnerability of a basin's mainstem river resulting from existing and potential conditions within the basin and combines the following three sub-indices (Supplementary Information). DEVI is also a useful tool to compare the potential hydrophysical impacts of proposed dams on the fluvial systems with the spatial distribution of biological diversity.

(i) Basin Integrity Index-BII, quantifies the vulnerability of the river basin to existing and potential land use change, potential erosion and runoff pollution;

(ii) Fluvial Dynamics Index-FDI, gauges the influences of fluxes of sediment transported by the rivers, the morphodynamic activity of the rivers, and the stage-range of the flood pulse;

(iii) Dam Impact Index- DII, quantifies how much of the river system will be affected by the planned and built dams.

DEVI values range from 0 to 100 , with higher values indicating greater vulnerability of a sub-basin.

The contribution of each individual index to the basin vulnerability is also examined (Fig. 2, Supplementary Figs.2 and 3 , and Table 1). 

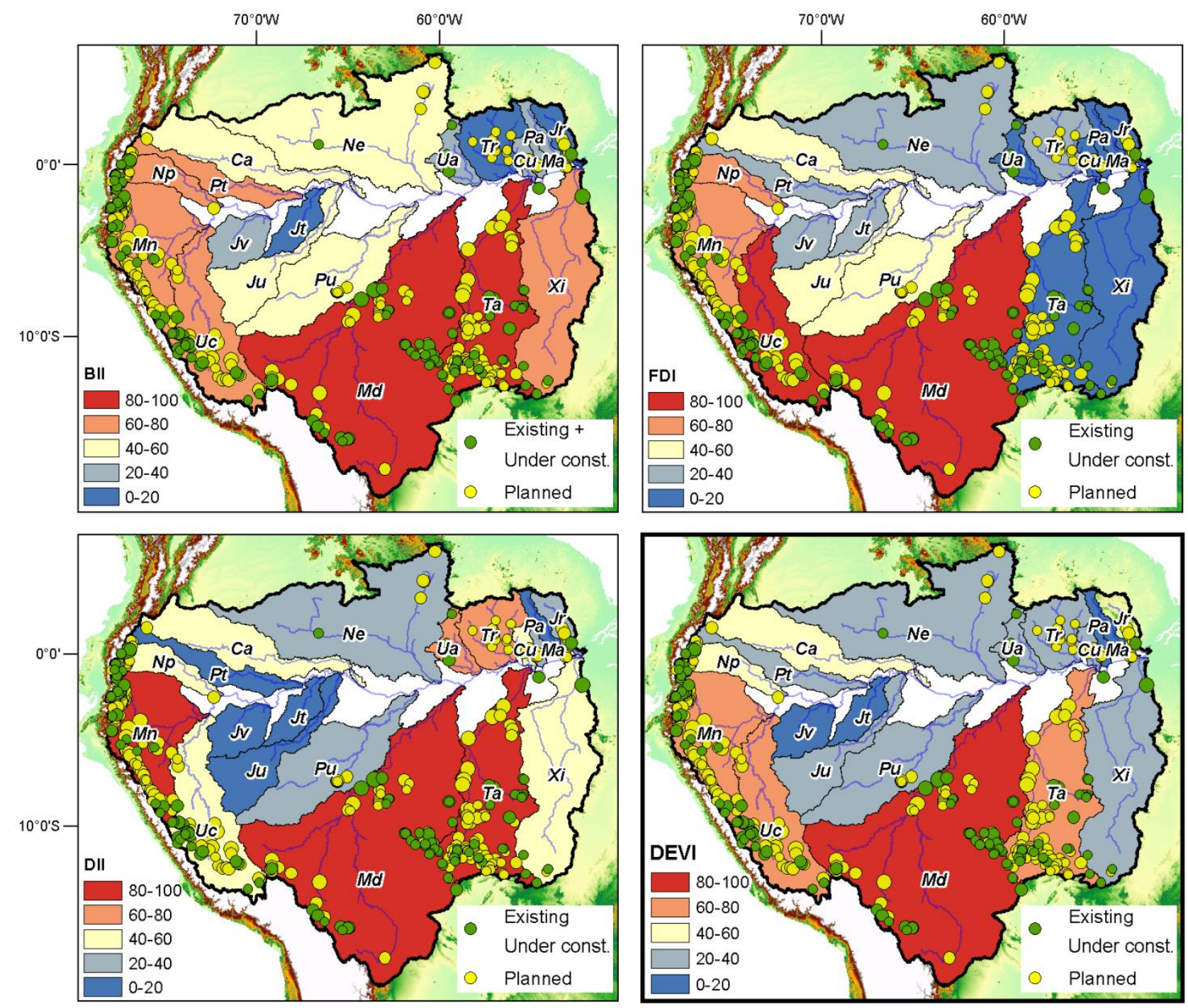

Fig. 2 Vulnerability Indices of Sub-Basins in the Amazon for existing, under construction, and planned dams: Basin Integrity Index $(B I I)$, Fluvial Dynamics Index $(F D I)$, Dam Impact Index $(D I I)$, and the combined Dam Environmental Vulnerability Index $(D E V I)$. Red colors indicate highest vulnerability based on the three indices; blue basins are least vulnerable. Dots indicate dam locations.

\section{Andean foreland sub-basins}

The Andean Cordillera (approximately 12\% of the Amazon basin area), provides more than $90 \%$ of the detrital sediment to the entire system ${ }^{12,18}$, out of which wetlands are constructed, and supplies most of the dissolved solids and nutrients transported by the mainstem Amazon River to its floodplains, estuary and coastal region ${ }^{19}$ (Fig. 1). The sediment yields of the Andean tributaries are among the highest on Earth, comparable to basins in the Himalaya and insular Southeast Asia ${ }^{20}$.

Among the five major Andean sub-catchments, three account for most of the planned, constructed and under-construction dams in this region: the Ucayali (47), Marañon (104), and Napo (21) (Fig. 1). The dams are located in areas of high sediment yield, at an average elevation of 1,500 meters (Fig. 1A and B). The upper Napo River basin in Ecuador underwent accelerated construction of dams in recent years and currently exhibits moderate DEVI (Supplementary Fig.3). However, when assessing the potential impact of planned dams, the most vulnerable rivers will be the Marañon and Ucayali, with DEVI of 72 and 61 respectively (Fig. 2). An additional environmental concern is that these threatened fluvial basins harbor a large diversity of birds, fish and trees ${ }^{21,22}$. Their BII values range from high to moderate. In general, the anthropogenic land cover of these watersheds is large $(>29 \%)$ and the amount of protected area upstream from the lowermost planned dam is relatively small (20-32\%). High values of FDI are mainly related to high sediment yields, high 
channel migration rates (MMR 0.046 ch-w $\mathrm{yr}^{-1}$ ) and moderate to high water stage variability (WSV). High rates of channel cutoff and abandonment result in oxbow lakes and atrophied branches, leading to increased sediment-storage. The Ucayali is the most sensitive river in this regard (Fig. 1). The Marañon River is critically threatened and its DII is very high because it would be impacted by a large number of dams concentrating along most of the mountainous course of the main channel (Figs. 1 and 2).

\section{Cratonic sub-basins}

The 10 cratonic sub-basins (Fig. 1) host rivers that drain moderate or low elevation Precambrian shields and old sedimentary and basaltic plateaus, and have low sediment yields, very low migration rates $\left(M R \sim 0.008 \mathrm{ch}-\mathrm{w}_{\mathrm{yr}^{-1}}\right)^{23}$, and moderate annual variability of mean water stage (WSV), resulting in low FDI values (Figs. 1 and 2).

Despite the fact that the main-stem of the Tapajós has not yet been disrupted by dams, this basin exhibits the largest values of $D E V I$ among cratonic basins due to the recent proliferation of constructed and under-construction dams on the major tributaries (Supplementary Fig. 2). The Xingu was recently impacted by Belo Monte, a megadam under construction (Supplementary Fig. 2). When assessing the impact of planned dams, the Tapajós is also the most threatened cratonic river, followed by the Xingu, Trombetas, and Uatumã $(D E V I<35)$ (Fig. 2). The BII is higher in the Tapajós subbasin (87) than in the Xingu basin (63), because the Tapajós has less protected area upstream of the lowermost dam and a larger deforestation rate. Anthropogenic land cover is large in both basins $(\sim 61 \%$ and $48 \%$ respectively) and anthropogenic disturbance of the landscapes, enabled by the scarcity of protected areas in southeastern cratonic basins, has begun to increase sediment supplies ${ }^{24}$ (Supplementary Fig.3).

The Tapajós will suffer significantly higher hydrophysical and ecological impacts than the Xingu because of the far larger number of planned dams distributed along hundreds of kilometers of the river. With all planned (90) and existing (28) dams in place, the Tapajós itself and all its major tributaries will be impounded. Together with the Madeira and Marañon, the Tapajós sub-basin is one of the most threatened in the Amazon basin (Fig. 2 and Supplementary Figs. 2 and 3). Despite limited knowledge about the biodiversity of this basin, the information available in environmental studies required by law to assess the impact of planed dams ${ }^{25,26}$ indicates that the Tapajós River harbors unique fish and bird species that are considered threatened by existing and planned dams, and some of the fish species are officially included in the Brazilian Ministry of the Environment List of species in risk of extinction (Supplementary Table 2). Concidently, our DEVI assessments point that the Tapajós River has to be a priority area for further detailed studies regarding impacts of dams on aquatic ecosystems and biodiversity.

Some smaller cratonic sub-basins such as the Jari (1 constructed, 4 planned dams) and Paru (3 planned dams), have relatively low DEVI values around 11, as a result of being well protected and having fewer planned dams (Fig. 2, Supplementary Fig. 3).

\section{Lowland sub-basins}

The lowland rivers drain Tertiary sedimentary rocks that remain mostly covered by rainforest. Because of their low gradients and lack of rapids, these rivers are free of dams. The 6 dams planned for the Purús River are not on the main channel, and for that reason its DEVI (34) is only moderate (Fig. 2). Anthropogenic land cover disturbance in these subbasins is also relatively low - Purús (24\%), Juruá (28\%), Jutaí (12\%) and Javari (18\%). However, the BII of the Purús and Juruá are 40 and 44 respectively (Fig. 2).

\section{Madeira sub-basin}

The Madeira River, the largest Amazon tributary in terms of drainage area, water and sediment discharge, had been highly impacted by the recent construction of dams and currently exhibits the largest values of DEVI of the whole Amazon basin (Supplementary Fig. 2). 
However, the future environmental perspective is even worse. With 83 dams planned or built, 25 on Andean tributaries, 56 on cratonic tributaries, and two on the mainstem Madeira River, is also the most threatened sub-basin in the Amazon $(D E V I>80)$ (Figs. 1 and 2). Nearly $80 \%$ of the Madeira River watershed, an area with high sediment yield, lies upstream of the Madeira River Hydroelectric Complex (MRHC), which consists of two recently constructed mega-dams (Santo Antônio and Jirau) and two planned dams at the Bolivian-Brazilian border and within Bolivia. The large potential impact to the Madeira sub-basin indicated by the DEVI is especially alarming as this sub-basin harbors high biological diversity associated with its fluvial habitats ${ }^{21,22}$.

The Madeira River FDI is characterized by low channel migration rates, high WSV $(12-14 \mathrm{~m})$ and high sediment yield. Cratonic tributaries generate $\sim 36 \%$ of the Madeira River discharge and have lower values of FDI (due to lower sediment load, water stage variability and migration rates) than the Andean-foreland tributaries but high DII because of the lengths and flooded areas of the impoundments. The dams planned for the Andean-foreland would impact major rivers (Madre de Dios, Beni, and Mamore Rivers) that have the highest sediment yields of the entire Andes-Amazon watershed (Fig. 1). The channel migration rates in these foreland rivers are very high, and the Beni and Mamore floodplains store $\sim 280 \mathrm{Mt}$ yr ${ }^{1}$ of sediment on the Bolivian plains ${ }^{27}$ while their WSV is moderate (Fig. 1).

The Madeira River accounts for approximately $50 \%$ of the total sediment transported into the Amazon River system from Bolivia and Peru, and sediment trapping by its large dams will be a major problem. Although assessments of sediment transport and trapping conducted by governmental and independent consultants are controversial ${ }^{28}$, it is estimated that $\sim 97 \%$ of the sandy load would be trapped upstream of the Santo Antônio and Jirau dams ${ }^{29}$. These estimates do not account for the trapping effects of the 25 upstream storage dams planned for the Andean reaches and upstream lowlands and palliative flushing strategies that may be implemented. Using satellite-based observations (Supplementary Text 2), we estimate the surface suspended sediment concentration (SSC), immediately downstream of the Santo Antônio dam for the years 2001-2015. Our results indicate that the Santo Antônio and Jirau dams caused a $20 \%$ decrease in the mean SSC of the Madeira River (Fig. 3), despite unusually high flood discharges in 2014 and 2015.

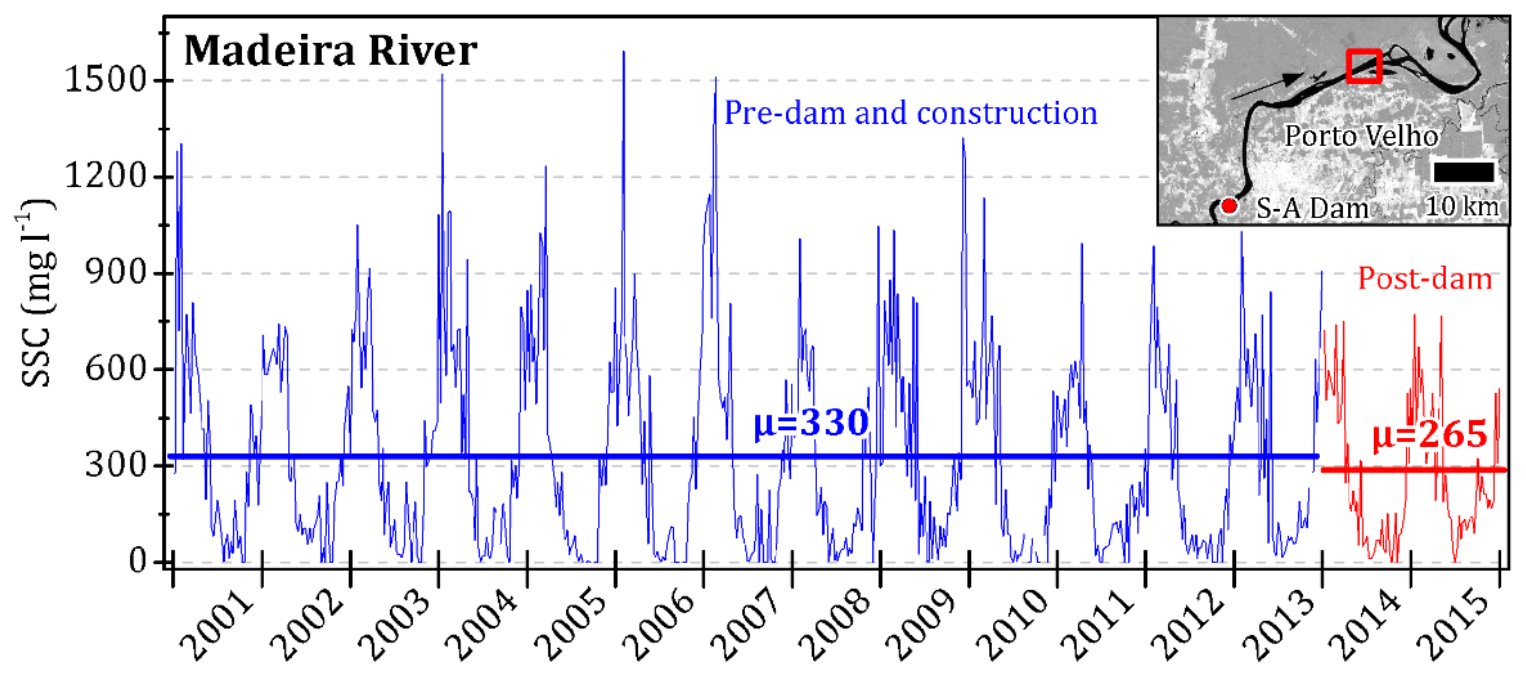

Fig. 3 Changes in surface suspended sediment concentration (SSC) in the Madeira River downstream of Santo Antônio Dam ( $8^{\circ} 48^{\prime} 06^{\prime}$ 'S , 63 $57^{\prime} 03^{\prime}$ 'W) for pre-and post-dam construction periods. Horizontal colored lines indicate mean surface suspended sediment concentrations $(\mu)$ for each period: pre-dam construction (2001-2013), and post-dam construction (2014-2015). A decrease of $20 \%$ in the mean annual SSC is detected in the Madeira River (methodological details in Supplementary Text 2). The red rectangle indicates the area used for the MODIS-SSC calibration. 


\section{The main-stem Amazon system and the Amazon sediment plume}

The Amazon River mainstem sustains a biologically rich floodplain with an area greater than $100,000 \mathrm{~km}^{230}$. Despite the high sediment yields of its Andean catchments, the Amazon basin sediment yield at the continental scale is only moderate ( 216 to $166 \mathrm{Mt} \mathrm{km}^{-2}$ ) because much of its sediment supply is stored in its floodplains. Along 2,000 km of the Brazilian Amazon, exchange of sediment between the channel and the floodplain exceeds the annual flux of sediment ( 800 to 1200

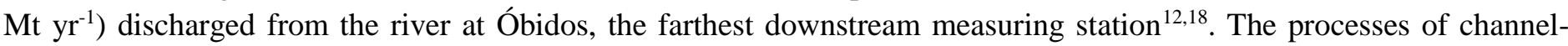
floodplain exchange include bank erosion, bar deposition, particle settling from diffuse overbank flow, and sedimentation in floodplain channels, levees and internal deltas, and are associated with a mean channel migration rate, $M R=0.02 \pm 20 \%$ ch-w $\mathrm{yr}^{-1}$ and a $W S V \sim 10 \mathrm{~m}^{18,31}$ (Fig. 1). Sediment storage along the whole Amazon River (channel-floodplain system) from the Peruvian border to Óbidos is approximately $500 \mathrm{Mt} \mathrm{yr}^{-1}$ (Fig.1). The lower Amazon River between Manacapuru and Óbidos, with its large fluvial lakes and wetlands, is a particularly crucial and vulnerable area from an ecological and geomorphological perspective. An estimated 162-193 $\mathrm{Mt} \mathrm{yr}^{-1}$ of sediment is stored in the floodplain along this reach of the Amazon River ${ }^{12}$. An additional estimated 300-400 $\mathrm{Mt} \mathrm{yr}^{-1}$ of sediment is deposited in the lower fluvial reach and delta plain $^{18}$ (Fig.1). The implied decrease of sediment along the main channel and floodplains of the main-stem Amazon will have major impacts on its sediment dynamics and ecology.

A recent vulnerability assessment suggested that the Amazon mouth is at "low to moderate risk" when compared to other deltas of the world (TWAP- Transboundary river basins: status and trends) ${ }^{32}$. However, these assessments in deltas are typically focused on land loss, and the mouth of the Amazon has more characteristics of an estuary than of a delta. The TWAP assessment of the Amazon mouth likely underestimates the cumulative effects of dams and the impacts on the environmental functions and services provided by the lower Amazon and its plume because the assessment apparently does not consider the current effects of very recently constructed dams nor the future effects of those dams that are under construction and planned.

The role of Amazon sediments on coastal and marine ecosystem functions is not fully understood. About 200-300 Mt $\mathrm{yr}^{-1}$ of muddy Amazon sediment is transported northwestward along the Atlantic continental shelf toward the Guyana and Venezuela coast ${ }^{33}$. These sediments provide substrate and nutrients for the largest preserved mangrove region of South America that spans Marajo Island, the coastline of Pará and Amapá states, Brazil, and the Guianas. Another recent discovery confirmed the existence of an extensive carbonate reef system of $\sim 9,500 \mathrm{~km}^{2}$ from the French Guiana border to Maranhão State in Brazil $(\sim 1,000 \mathrm{~km})$, with unique functional attributes due to the plume influence, which provides ecosystem services and acts as a selective biogeographic corridor between the Caribbean and the South Atlantic Ocean ${ }^{34}$. Our understanding of the environmental links and mechanisms of interactions between the Amazon plume and the coral reef is still rudimentary.

It has been suggested that the Amazon plume may also have inter-hemispheric climate effects, influencing precipitation in the Amazon forest as well as moisture convergence into Central America, the number and intensity of summer storms, and storm trajectories toward the Caribbean, Central America and the southern United States ${ }^{35}$.

\section{Sustainable solutions for Amazonian rivers}

There is major ongoing debate about the costs and benefits of building large dams and water development planners, engineers, and economists have been shown to be overly optimistic and to systematically underestimate $\operatorname{costs}^{36}$. The costs of dams are much more difficult to estimate than other energy projects because each dam must be constructed to work within its particular environmental, geological, and hydrological conditions ${ }^{36}$. Although large-scale hydropower is often seen as an attractive possibility for the Amazon region, economic uncertainties driven by climate change, land use change, and sensitivity to extreme drought events, greatly affect projections of the economics of operation and power generation $^{37,38}$.

Recent research has shown that, even before taking into account negative impacts on human society and the environment, on average the actual construction costs of large dams tend to be too high to yield a positive financial return on investment $^{9,10,36,39}$. Estimated benefits from water development are likely to be realized, but the unexpected environmental 
and social costs that typically occur with every dam project detract from the net benefits ${ }^{40}$. A global analysis of 245 large dams including 26 major dams built between 1934 and 2007, demonstrated that actual costs averaged 96\% (median 27\%) higher than predicted, and one out of ten dams costs three times its estimate ${ }^{36}$.

Furthermore, most of the dams, even those in Peru and Bolivia, are planned for exporting energy from their regions to cover Brazil's growing national demand for electricity, which was projected to increase about $2.2 \%$ annually up to $2050^{41,42}$. However, in the current economic situation the Brazilian government is reassessing this macroeconomic forecast and accepts that the middle-term growth rates of electricity demand are below previous estimates, that national plans for greater energy security overestimated the need for infrastructure, and that the demand by 2022 could be fully met with only $60 \%$ of the planned investments ${ }^{43}$. Thus, we suggest that the economic need and economic viability of dam construction in Brazil and the Andean countries need to be re-assessed. After the construction of three controversial megadams (Belo Monte, Jirau and Santo Antônio), the Amazon countries have a second chance to reflect on the sustainable future of their unique fluvial resources.

We propose that is essential for government agencies in all countries of the Amazon basin to formally recognize the gradually unfolding, but enormous, scale of dam-building impacts propagating through the riverine and coastal systems of the entire region, so that they can accurately assess, plan for, and avoid or ameliorate, foreseeable degradation of the ecosystem services of these incomparable wetlands. Such recognition could provide a basis for trans-boundary communication and cooperation; a few examples are suggested herein.

Current legislation only partially considers policies for national and international waters ${ }^{44}$, and the licensing process to approve large infrastructure projects has been simplifed and weakened (Box 1). At a basin scale, it is critical to revitalize, improve, and expand policy instruments such as the Amazon Cooperation Treaty (ACT) and its Organization (ACTO), and to build new international actions based on existing legal instruments already available in Brazil but still inoperative in the Amazon, such as the Water Management Act (Law 9433/1997) that promotes an integrated water management system (Box 1).

ACTO could be the catalyst to build new international actions, policies, and plans for river management. ACTO could also strengthen its technical and scientific capacity, consolidate existing programs, and encourage more active participation of natural and social scientists engaged with stakeholders and decision makers. Those specialists could provide technical and scientific data such as monitoring trends in sediment loads, extent of wetland inundation, overbank flooding frequencies, coastal sediment plume size, riparian deforestation; anticipate environmental-socioeconomic impacts; and suggest strategies for basin and resource management, as well as for conflict avoidance.

We suggest that a Legal Transboundary Water Resources Framework is required that has as its premise an integrative basin-scale approach. Proposals for the use of water resources by different agencies (energy, transportation, and environment) must be combined into basin-scale, multi-faceted frameworks, rather than being isolated as independent competing entities. Social participation and basin-integrated management among states/department units of Peru, Brazil and Bolivia, such as the MAP collaboration for integrated management of the Acre River (a tributary of the Purús River) (Box 1), is an encouraging solution ${ }^{45}$. However, such regional plans need to be incorporated into a major decision management tree at basin scale and not simply atomized among a plethora of widely dispersed, independent, small projects in the basin.

A commission linked to ACTO, supported by an international panel of multidisciplinary experts (Amazon Basin Panel$\mathrm{ABP}$ ) could produce assessments of the natural capital and its functioning, together with an assessment of socio-economic demands, conflicts and trends along waterways of Amazon River basin, and defining Integrated and Sustainable Management plans for Transboundary Water Resources. In that context, the assessment of vulnerability and impacts is a fundamental step. The DEVI measurement of vulnerability at sub-basin scales demonstrates that the recent construction of dams is profoundly impacting the system, and predicts that, if the planned dams are constructed, their cumulative effect will increase the complexity and scale of the impacts. Our assessment also reveals why downstream nations and Brazilian states, that are not directly involved in the construction of dams in their sovereign territories, are still vulnerable to indirect environmental impacts and thus have reason to assess the consequences of dam building far upstream of their borders. 


\section{Box 1}

The Amazon Cooperation Treaty-ACT, signed by Brazil, Bolivia, Colombia, Guyana, Ecuador, Peru, Venezuela and Suriname, aims to promote the sustainable development of these Amazon countries. It is the juridical instrument that recognizes the transboundary character of the Amazon River basin. Its executive organization is the Amazon Cooperation Treaty Organization-ACTO. The countries of the Amazon basin (except Guyana) are also signatories of the Ramsar Convention which stipulates the sustainable use of wetland resources, rivers and other continental wetlands.

Among ACTO members, Brazil is at the forefront regarding water policies and legislation. The nation's main legal framework for this is the Brazilian Water Management Act (Law 9433/1997). The law sets standards for a decentralized and participative water resources management system; considers river basins as the fundamental territorial units; defines strategies for water planning, management and governance; and contemplates the creation of river basin committees RBCs. The RBCs, formed by representatives of the government sector, water users and civil society, are responsible for defining strategies for basin management, river basin planning, and conflict mediation. The creation of a Participative Basin Committee-PBC for the Amazon could follow the general lines of work and responsibility of the RBCs.

Ongoing international basin management policies in the Amazon are nascent and concentrated in the MAP region, the Madre de Dios, Acre, and Pando departments, in Peru, Brazil and Bolivia respectively. MAP aims to collaborate on the integrated management of the Acre River and it is the only international water initiative formed by civil society in the entire Amazon basin ${ }^{45}$.

The main tool in Brazil and some Amazon countries for environmental governance and licensing is local environmental impact assessment (EIA), which in most cases does not provide adequate technical information for, and thus has had minimal influence on, policy decisions ${ }^{58}$. Additional tools such as Strategic Environmental Assessments (SEA) and Integrated Environmental Assessments (IEA) are being tried in Brazil, but the EIA is still the only legal mandatory instrument for licensing. In Amazonian countries, the scale of assessment currently required for construction of dams is entirely local, and the decision-making process does require adequate analysis of hydrophysical and ecological impacts for the entire river system and coastal zone ${ }^{59,60}$. Improvements in the technical requirements of Term of References (TOR), integrated assessment at basin scale, and scrutiny of project viability by ACTO, and the proposed PBC and ABP, are required.

A proposal in Brazil to amend the federal constitution (PEC-65/2012-Brazilian Senate) will weaken environmental licensing for infrastructure projects by eliminating the current three-step process - preliminary, installation, and operational - in favor of a simpler, but watered-down, EIA ${ }^{61,62}$.

Brazil modified its Forestry Code in 2012 facilitating legal deforestation of large portions of the Amazon floodplains ${ }^{63}$. Some legally protected areas were also de-gazetted or downsized to make room planned and existing dams that overlap with conservation areas. These trends reverse the trend toward global environmental leadership shown by Brazil during recent decades. Change is needed to include an upscaling of cost-benefit analyses to encompass regional and transnational basin-wide values.

ABP assessments could also provide the scientific basis for governments and society at all levels to develop policies that recognize the fundamental connectedness of river and coastal environments. We suggest participative strategies replicating the management of the Intergovernmental Panel on Climate Change-IPCC, involving members from ACTO countries, and additional members (e.g., France), and by opening the participation to scientists and international scrutiny by peers. Like IPCC reports, the ABP assessments could be policy-relevant but not policy-prescriptive. They may present projections of environmental impacts and issues based on different scenarios, and help suggest to policymakers a range of potential sustainable policies for river management. 
The decision-making processes could be supported further through the creation of a Participative Basin Committee with representatives of the different socio-political actors to discuss and define recommendations that consider socioenvironmental governance and protecting collective rights ${ }^{46}$, under the coordination of ACTO (Box 1). Into that institutional context, a further policy instrument we suggest for reversing national-regional scale environmental degradation is the creation of new conservation units (CUs) in the Amazon and hydro-socio-economic-ecological zoning regulations. These CUs could be explicitly designed to recognize and protect watersheds, main channels, floodplains and eco-hydro-geomorphological services; and assess sites of significant natural, cultural, aesthetic-scenic and economic value to local communities.

Regarding energy policies, the medium-term demand for electricity can be met without sacrificing Amazon fluvial and coastal ecosystems and economies. One-off megaprojects -e.g., in the form of large dams, large coal or nuclear plants face disproportionate risks, which make them relatively unattractive compared to the more replicable alternatives ${ }^{36,39,47}$. Preliminary evidence suggests that modular solutions including wind, solar, and on-site combined heat, cooling, and power plants- provide compelling alternatives not only environmentally but also financially ${ }^{48}$.

More flexible measures in Amazon countries could facilitate a smooth transition to a more diverse energy matrix based on other renewable sources in the middle-to-long term, protecting the ecological services provided by the great, undammed Amazon rivers. Brazil, for example, has a huge potential for the production of wind energy, (>143 GW), solar energy, and a variety of alternatives for hydropower besides large dams (small hydroelectric plants-SHP, river hydrokinetic energy-RHK $)^{49-52}$. Currently, Brazil would be losing approximately $20 \%$ of the energy due to defficien transmission ${ }^{53}$. Using a conservative projection, improvements in the transmission and distribution system and repowering and modernizing existing hydropower plants could increase energy delivery of approximately $2.84 \%{ }^{54}$. Peru also has a remarkable potential for wind, solar and geothermal energy but very litte has been used ${ }^{55,56}$.

Contrary to current policy, the energy sector needs to be a part of integrated Amazon-basin planning and management initiatives. At present, the energy sector tends to operate in the region as an independent agent imposed through vertical and centralized governmental decisions, but without a participative process that considers the needs and expectations of the local communities and that integrates the multidisciplinary scientific and technical information concerning the character and functioning of the Amazon River basin at multiple scales and locations, into political and socio-economic analyses. Science played a critical role in reducing deforestation in Brazil through monitoring systems, by assessing the role of forests in regional climate regulation, and by showing that agricultural production could be increased without further deforestation ${ }^{57}$. We propose that through the integration of available scientific knowledge, it will be possible to apply analogous strategies to the protection of natural resources in the Amazon fluvial and coastal systems.

Citizens of the Amazon basin countries will ultimately have to decide whether hydropower generation is worth the price of causing profound damage to the most diverse and productive river system in the world. If those decisions are taken with a comprehensive understanding of the fluvial system as a whole, the many benefits they provide to humans could be retained utilizing a long-term vision for natural conservation and sustainable development.

\section{References}

1 Castello, L. \& Macedo, M. N. Large-scale degradation of Amazonian freshwater ecosystems. Global change biology (2015).

2 Winemiller, K. et al. Balancing hydropower and biodiversity in the Amazon, Congo, and Mekong. Science 351, 128-129 (2016).

3 Davidson, E. A. et al. The Amazon basin in transition. Nature 481, 321-328 (2012).

4 Fearnside, P. M. Emissions from tropical hydropower and the IPCC. Environmental Science \& Policy 50, 225239 (2015).

5 Latrubesse, E. M. Patterns of anabranching channels: The ultimate end-member adjustment of mega rivers. Geomorphology 101, 130-145, doi:DOI 10.1016/j.geomorph.2008.05.035 (2008).

6 Syvitski, J. P., Vörösmarty, C. J., Kettner, A. J. \& Green, P. Impact of humans on the flux of terrestrial sediment to the global coastal ocean. Science 308, 376-380 (2005). 
Nilsson, C., Reidy, C. A., Dynesius, M. \& Revenga, C. Fragmentation and flow regulation of the world's large river systems. Science 308, 405-408 (2005).

8 Grill, G. et al. An index-based framework for assessing patterns and trends in river fragmentation and flow regulation by global dams at multiple scales. Environmental Research Letters 10, 015001 (2015).

9 WCD - World Commission on Dams. Dams and Development: A New Framework for Decision-making: the Report of the World Commission on Dams. (Earthscan, 2000).

10 Scudder, T. T. The Future of Large Dams:" Dealing with Social, Environmental, Institutional and Political Costs". (Taylor \& Francis, 2012).

11 Junk, W. J. The central Amazon floodplain: ecology of a pulsing system. Vol. 126 (Springer Science \& Business Media, 2013).

12 Filizola, N. \& Guyot, J. L. Suspended sediment yields in the Amazon basin: an assessment using the Brazilian national data set. Hydrological Processes 23, 3207-3215, doi:Doi 10.1002/Hyp.7394 (2009).

13 Meade, R. H., Dunne, T., Richey, J. E., Santos, U. d. M. \& Salati, E. Storage and remobilization of suspended sediment in the lower Amazon River of Brazil. Science 228, 488-490 (1985).

14 Latrubesse, E. M., Stevaux, J. C. \& Sinha, R. Tropical rivers. Geomorphology 70, 187-206, doi:DOI 10.1016/j.geomorph.2005.02.005 (2005).

15 Park, E. \& Latrubesse, E. M. Surface water types and sediment distribution patterns at the confluence of mega rivers: The Solimões-Amazon and Negro Rivers junction. Water Resources Research 51, 6197-6213 (2015). Salo, J. et al. River dynamics and the diversity of Amazon lowland forest. Nature 322, 254-258 (1986). Largescale natural forest disturbance and primary forest succession in the Amazon lowlands are caused by fluvial lateral erosion and channel changes.

Junk, W. J., Bayley, P. B. \& Sparks, R. E. The flood pulse concept in river-floodplain systems. Canadian special publication of fisheries and aquatic sciences 106, 110-127 (1989). In flood-pulsing systems of large riverfloodplains, habitat diversity is especially wide-randing because the duration, amplitude, frequency, and predictabiity of flooding, and the nutrient status of the floodplain depends on the amount and quality of dissolved and suspended solids provided by the pulse.

Dunne, T., Mertes, L. A. K., Meade, R. H., Richey, J. E. \& Forsberg, B. R. Exchanges of sediment between the flood plain and channel of the Amazon River in Brazil. Geological Society of America Bulletin 110, 0450 (1998). Exchanges between channel and floodplain along the Amazon River exceed the annual flux of sediments at Óbidos, and hundreds of millions of tons of sediments are stored in the floodplain.

19 Stallard, R. \& Edmond, J. Geochemistry of the Amazon: 2. The influence of geology and weathering environment on the dissolved load. Journal of Geophysical Research: Oceans 88, 9671-9688 (1983).

20 Latrubesse, E. M. \& Restrepo, J. D. Sediment yield along the Andes: continental budget, regional variations, and comparisons with other basins from orogenic mountain belts. Geomorphology 216, 225-233 (2014).

21 Vale, M. M., COHN-HAFT, M., Bergen, S. \& Pimm, S. L. Effects of future infrastructure development on threat status and occurrence of Amazonian birds. Conservation Biology 22, 1006-1015 (2008).

22 Queiroz, L. J. et al. Peixes do Rio Madeira - Y-Cuyari Pirá-Ketá. 1163 (São Paulo: Editora Dialeto, São Paulo, 2013).

23 Constantine, J. A., Dunne, T., Ahmed, J., Legleiter, C. \& Lazarus, E. D. Sediment supply as a driver of river meandering and floodplain evolution in the Amazon Basin. Nature Geoscience 7, 899-903 (2014). Rivers with high sediment loads experience higher annual migration rates than those with lower sediment loads.

24 Latrubesse, E., Amsler, M., De Morais, R. \& Aquino, S. The geomorphologic response of a large pristine alluvial river to tremendous deforestation in the South American tropics: The case of the Araguaia River. Geomorphology 113, 239-252 (2009).

25 MMA. Portaria No 445 de 17 de Dezembro de 2014. Lista Nacional Oficial de Espécies da Fauna Ameaçadas de Extinção - Peixes e Invertebrados Aquáticos. (DF: Diário Oficial da União; Ministério do Meio Ambiente (MMA), Brasília, Brasil, 2014).

26 CNEC Worley Parsons Engenharia, S. A. EIS HD Sao Luiz do Tapajós: Environmental impact study, hydroelectric development Sao Luiz do Tapajós. (Consórcio Nacional dos Engenheiros Consultores, Sao Paulo, 2014).

27 Guyot, J. L., Filizola, N., Quintanilla, J. \& Cortez, J. Dissolved solids and suspended sediment yields in the Rio Madeira basin, from the Bolivian Andes to the Amazon. Erosion and Sediment Yield: Global and Regional Perspectives, 55-63 (1996).

28 Fearnside, P. Decision-making on Amazon dams: Politics trumps uncertainty in the Madeira River sediments controversy. Water Alternatives 6, 313 (2013). 

(2006).

30 Hess, L. L. et al. Wetlands of the lowland Amazon basin: Extent, vegetative cover, and dual-season inundated area as mapped with JERS-1 Synthetic Aperture Radar. Wetlands 35, 745-756 (2015).

31 Park, E. \& Latrubesse, E. M. Modeling suspended sediment distribution patterns of the Amazon River using MODIS data. Remote Sensing of Environment 147, 232-242, doi:DOI: 10.1016/j.rse.2014.03.013 (2014). UNEP. Transboundary River Basins: Status and Trends. 342 (UNEP-DHI and UNEP, Nairobi, 2016).

Nittrouer, C. A., Kuehl, S. A., Sternberg, R. W., Figueiredo, A. G. \& Faria, L. E. An introduction to the geological significance of sediment transport and accumulation on the Amazon continental shelf. Marine Geology 125, 177-192 (1995).

34 Moura, R. L. et al. An extensive reef system at the Amazon River mouth. Science advances 2, e1501252 (2016).

35 Vizy, E. K. \& Cook, K. H. Influence of the Amazon/Orinoco Plume on the summertime Atlantic climate. Journal of Geophysical Research: Atmospheres (1984-2012) 115 (2010).

Ansar, A., Flyvbjerg, B., Budzier, A. \& Lunn, D. Should we build more large dams? The actual costs of hydropower megaproject development. Energy Policy 69, 43-56 (2014). In most countries large hydropower dams will be too costly in absolute terms and take too long to build to deliver a positive risk-adjusted return.

37 Schaeffer, R., Szklo, A., De Lucena, A. F. P., Soria, R. \& Chavez-Rodriguez, M. The vulnerable Amazon: the impact of climate change on the untapped potential of hydropower systems. IEEE Power and Energy Magazine 11, 22-31 (2013).

Stickler, C. M. et al. Dependence of hydropower energy generation on forests in the Amazon Basin at local and regional scales. Proceedings of the National Academy of Sciences 110, 9601-9606 (2013). overruns: Testing six hypotheses. Energy 74, 906-917 (2014). Stone, R. The legacy of the three gorges dam. Science 333, 817-817 (2011). EPE. Demanda de Energia, 2050. (Empresa de Pesquisa energética-EPE, Rio de Janeiro, 2014).

Berardi, U. Building energy consumption in US, EU, and BRIC countries. Procedia Engineering 118, 128-136 (2015).

43 Prado, F. A. et al. How much is enough? An integrated examination of energy security, economic growth and climate change related to hydropower expansion in Brazil. Renewable and Sustainable Energy Reviews 53, 11321136 (2016).

SAE. Recursos Hídricos Fronteiriços e Transfronteiriços do Brasil. 144 (Secretaria de Asuntos Estratégicos-SAE, Brasilia, Brazil, 2013).

45 SEMA. Plano estadual de recursos hídricos do Acre. 243 (Secretaria de Estado de Meio Ambiente, Rio Branco, Brazil, 2012).

46 Little, P. Mega-Development Projects in Amazonia: A Geopolitical and Socioenvironmental Primer. 96 (Lima, Peru, 2014).

47 Flyvbjerg, B. What you should know about megaprojects and why: An overview. Project Management Journal 45, 6-19 (2014).

48 Ansar, A., Flyvbjerg, B., Budzier, A. \& Lunn, D. Big is Fragile: An Attempt at Theorizing Scale. (2016).

49 Malagueta, D. et al. Potential and impacts of Concentrated Solar Power (CSP) integration in the Brazilian electric power system. Renewable Energy 68, 223-235 (2014).

50 WWF. Alem das grandes hidreletricas: políticas para fontes renovaveis de energia no Brasil. (2012).

51 Filizola, N. et al. Preliminary Analysis of Potential for River Hydrokinetic Energy Technologies in the Amazon Basin. IDB Technical Note (Energy Division); IDB-TN-891 (2015).

52 Pereira, M. G., Camacho, C. F., Freitas, M. A. V. \& Da Silva, N. F. The renewable energy market in Brazil: Current status and potential. Renewable and Sustainable Energy Reviews 16, 3786-3802 (2012).

53 Rey, O. Um olhar para as grandes perdas de energia no sistema de transmissão elétrico brasileiro. Setor Elétrico Brasileiro e a Sustentabilidade no Século 21, 40-44 (2012).

54 EPE. Repotentiação e Modernização de Usinas Hidrelétricas. (Empresa de Pesquisa energética-EPE, Rio de Janeiro, 2008).

55 Meisen, P. \& Krumpel, S. Renewable energy potential of Latin America. California, USA: Global Energy Network Institute. http://www. geni. org (2009).

56 IRENA. Peru Renewables Readiness Assessment 2014. (International Renewable Energy Agency, Abu Dhabi, 2014). 
57 Nobre, C. A., Marengo, J. A. \& Artaxo, P. Understanding the climate of Amazonia: Progress from LBA. Amazonia and Global Change, 145-147 (2009).

58 Ritter, C. D. et al. Environmental impact assessment in Brazilian Amazonia: Challenges and prospects to assess biodiversity. Biological Conservation 206, 161-168 (2017).

59 Ferreira, J. et al. Brazil's environmental leadership at risk. Science 346, 706-707 (2014).

60 WDPA. World database on protected areas. World Conservation Union and UNEP-World Conservation Monitoring Centre, New York, New York, USA (2004).

61 Fearnside, P. M. Brazilian politics threaten environmental policies. Science 353, 746-748 (2016).

62 Wade, L. Brazilian crisis threatens science and environment. Science 352, 1044-1044 (2016).

63 de Sousa Jr, P. T., Piedade, M. T. F. \& Candotti, E. Ecological oversight: Brazil's forest code puts wetlands at risk. Nature 478, 458-458 (2011).

Acknowledgements This research was supported partially by NSF grants (FESD-1338694, EAR-1147954 and DDRI1558446), NASA grant (NAG5-6120), National Geographic Society-Research and Exploration Grant (8855-10), LLILAS-Mellon, Brazilian Council for Scientific and Technological Development-CNPq and CAPES Foundation.

Author Contributions E.L. initiated this research, conceived the multidisciplinary methodology, and coordinated the manuscript. All the authors extensively contributed to the writing and analysis of results. Regarding specific cartographic products and data base: E.L., E.P., and C.W. developed the database on dams. E.A., C.W., and E.P. performed GIS analysis. E.P. performed remote sensing work. 